\title{
PENGEMBANGAN PROGRAM STIMULASI GERAK UNTUK MENGOPTIMALKAN PERKEMBANGAN MOTORIK KASAR BAYI USIA 0 - <12 BULAN
}

\author{
Widya Ayu Puspita \\ e-mail: widya.ayu.puspita@gmail.com \\ BPPAUDNI Regional II Surabaya, Jawa Timur
}

\begin{abstract}
Abstrak: Pengembangan program yang dilakukan bertujuan untuk mengembangkan ragam stimulasi gerak yang tepat untuk bayi usia $0-<12$ bulan sehingga mereka dapat berkembang dan tumbuh sesuai dengan pola cephalocaudal dan proximodista. Dalam pengembangan program ini, bayi diberikan sejumlah perlakuan sehingga mencapai tujuan yang dimaksud. Penelitian ini dilakukan pada bulan Januari sampai dengan Maret 2013. Hasil penelitian menunjukkan bahwa terdapat perbaikan dalam perkembangan motorik kasar pada bayi yang mendapatkan stimulasi gerak. Dengan demikian, penelitian ini menyarankan agar proses stimulasi dilanjutkan, sehingga bayi dapat tumbuh dan berkembang secara optimal.
\end{abstract}

Kata-kata Kunci: stimulasi gerak, motoric kasar,cephalocaudal, proximodistal.

\section{THE DEVELOPMENT OF MOTOR STIMULATION PROGRAM TO OPTI- MIZE THE DEVELOPMENT HARD MOTOR FOR BABY 0 - <12 MONTHS}

\begin{abstract}
This program development aimed to develop gross motor stimulation for babies (0 - $<12$ months), so they can develop and growth well by cephalocaudal and proximodistal pattern. In the program development, the babies are given a number of treatments to achieve the objectives. The research findings indicates a gross motor development improvement for the babies who get right gross motor stimulation. Therefore, the research suggests to continue the process that the babies can grow and develop optimally.
\end{abstract}

Keywords: stimulation, gross motor stimulation, cephalocaudal, proximodistal

\section{PENDAHULUAN}

Masa usia dini adalah masa kritis perkembangan gerak dan kecakapan khusus motorik kasar yang berupa gerak fundamental. Kecakapan gerak fundamental merupakan periode pembelajaran yang sensitif untuk pengendalian tubuh dan pengelolaan lingkungan, karena pada saat itu terjadi perkembangan dan pembentukan neuron kompleks yang penting untuk aktivitas tubuh.

Bayi yang baru lahir memang memiliki keterampilan motorik yang terbatas, namun refleks (gerakan otomatis) membantu perilaku yang baru lahir. Kematangan sensorimotorik merupakan tahap penting pada usia 0 - 12 bulan. Bayi menerima stimulus dari sekitarnya menggunakan aktivitas motorik dan inderawinya. Semakin bertambah usia bayi, semakin meningkat pula keterampilan motoriknya.

Pada dasarnya, ada dua jenis keterampilan motorik pada bayi, yaitu keterampilan motorik kasar dan halus. Keterampilan motorik kasar meliputi kegiatan-kegiatan otot besar, seperti menggerakkan lengan, merayap, merangkak dan berjalan. Kegiatan tersebut penting terkait perkembangan motorik kasar terjadi pada kira-kira usia 12 hingga 13 bulan. Keterampilan motorik halus melibatkan otot-otot yang lebih kecil, dengan tingkat koordinasi yang lebih tinggi pada kemampuan menggenggam, meraih, melepas, atau dapat juga disebut keterampilan pada telapak tangan dan jemari.

Menurut Santrock 1995 perkembangan fisik anak berjalan maju seiring dengan pertambahan usia anak. Apabila terjadi perkembangan yang mundur, maka dimungkinkan terjadi penyimpangan atau gangguan sehingga perlu diwaspadai agar dapat dilakukan intervensi dini. Secara universal, Santrock (1995:148) perkembangan keterampilan motorik bayi disajikan dalam gambar 1 berikut ini. 


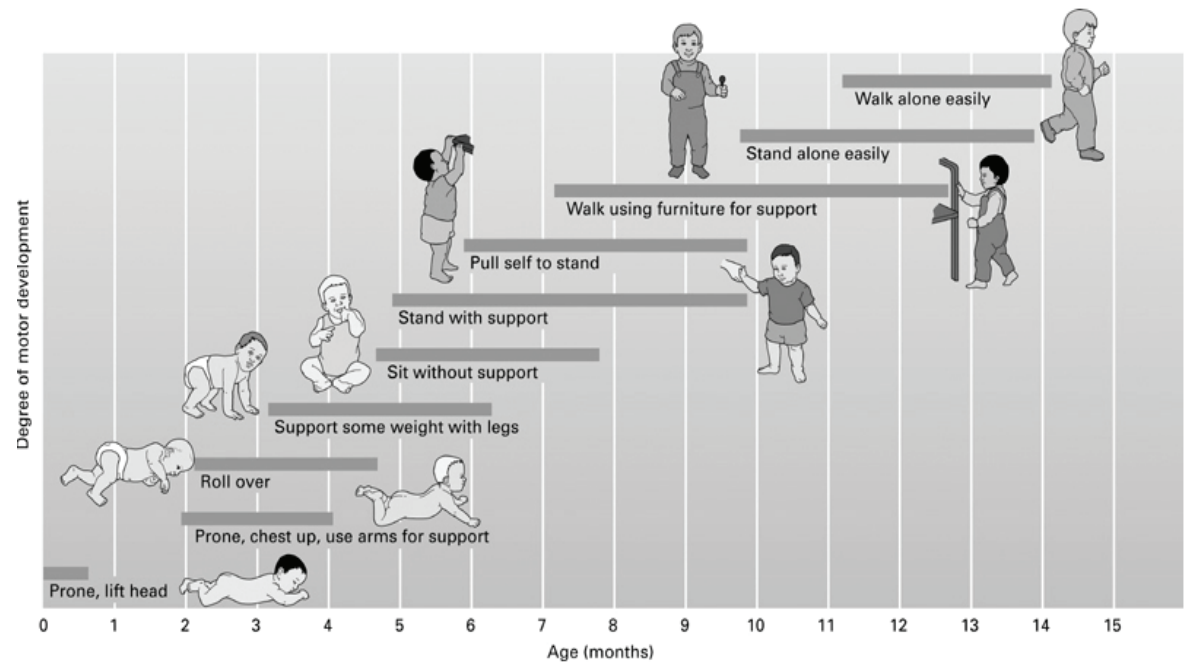

Gambar 1. Perkembangan Keterampilan Motorik Bayi

Sumber : Santrock (1995:148)

Perkembangan motorik kasar pada masa bayi menjadi prioritas tugas perkembangan dan pada umumnya dipengaruhi oleh kematangan fisik anak usia bayi (Papalia \& Feldman, 2012). Namun demikian, stimulasi yang lebih intensif dan tepat perlu diberikan, sehingga terjadi peningkatan persentase anak usia dini yang mencapai perkembangan fisik motorik secara optimal. Anak bertumbuh dan berkembang secara progresif. Bayi lahir, mengembangkan gerak refleks, lalu menuju pada gerak yang terkoordinasi, mulai berguling, duduk dan berjalan. Inilah yang disebut sebagai tonggak-tonggak perkembangan (milestones development). Sebagian besar anak, belajar untuk melakukan sesuatu sesuai dengan usianya, akan tetapi terdapat pula beberapa pengecualian pada beberapa anak yang lain. Oleh karena usia sangat terkait dengan perkembangan, maka tonggak-tonggak perkembangan seharusnya digunakan hanya sebagai pedoman umum.

Kecakapan motorik kasar adalah kecakapan yang digunakan untuk menggerakkan seluruh tubuh, lengan, dan kaki, dan yang termasuk di dalamnya seperti berlari, melompat, berjalan dan keseimbangan. Perkembangan kecakapan ini dimulai sejak anak berada dalam kandungan dan berlanjut sepanjang kehidupan. Perkembangan motorik kasar secara umum saling berhubungan antara satu sama lainnya, dan saling mendukung antar tahap perkembangan, sehingga apabila ada tahap perkembangan yang menyimpang atau terlambat, maka kecakapan yang lebih tinggi juga akan mengalami keterlambatan atau bahkan tidak berkembang.

Pada masa bayi, pertumbuhan dan perkembangan berlangsung sangat pesat dari bulan ke bulan. Banyak gerakan yang dibuat pada bulan-bulan pertama kehidupan adalah gerakan refleksif. Refleks merupakan respons stereotip terhadap rangsangan tertentu dan dilakukan tanpa keterlibatan otak yang mengendalikan kesadaran. Refleks pertama, yang dikenal sebagai 'primitive' reflex (refleks janin), seperti memegang benda-benda yang tersentuh oleh bayi dan refleks mengisap, secara bertahap diambil alih oleh otak, berkembang dalam enam bulan pertama kehidupan akan terintegrasi menjadi 'postural' reflex. Refleks integrasi memberikan dasar untuk kontrol sadar postur, keseimbangan dan koordinasi dalam lingkungan berbasis gravitasi.

Jika transisi dari refleks janin ke refleks integrasi tidak selesai dalam tiga setengah tahun pertama kehidupan, anak akan mengalami masalah dengan keseimbangan dan koordinasi. Keseimbangan dan refleks menghisap, misalnya, dapat mengganggu perkembangan bicara yang jelas sebagai kontrol dari otot-otot di bagian depan mulut yang terpengaruh dan posisi lidah. Refleks menggenggam dapat mempengaruhi genggaman pensil ketika mencoba untuk menulis karena ibu jari terkait di bawah jari-jari ketika pena atau pensil ditempatkan di antara jempol dan telunjuk.

Refleks lain yang terhubung ke fungsi mekanisme keseimbangan mempengaruhi aspek-aspek tertentu dari pembelajaran. Mekanisme keseimbangan yang terletak di telinga bagian dalam terhubung ke pusat-pusat di otak yang terlibat dalam pengendalian tubuh, gerakan mata dan regulasi serta modulasi output gerak.

Agar mekanisme tubuh berfungsi dengan baik, keseimbangan juga diperlukan guna memahami sensasi arah refleks tonik leher asimetris yang dapat mempengaruhi tulisan tangan, gerakan mata horizontal dan pengembangan lateralitas (penggunaan dari sisi yang 
sama untuk mata kaki tangan, dan telinga). Refleks tonik leher simetris mempengaruhi koordinasi antara bagian atas dan bawah tubuh, berhubungan dengan sebagian otot dan sering dapat dilihat pada anak yang memiliki postur duduk yang buruk dan yang cenderung merosot di meja saat menulis.

Jika pernah melihat bayi di tempat tidur, maka dapat dilihat bahwa bayi melakukan sedikit goyangan yang merupakan gerakan ritmis. Gerakan-gerakan yang terprogram dalam otak bayi (refleks primitif) dan sangat penting untuk perkembangan otak yang sehat. Semua bayi lahir dengan refleks primitif. Refleks primitif adalah segala faktor yang membuat bayi mulai mengangkat kepalanya, berguling, meletakkan segala sesuatu di mulutnya, batu di tangan dan lutut, merangkak, dan akhirnya berjalan. Kadang-kadang bayi melewatkan salah satu tahap perkembangan, yang dapat menyebabkan masalah di kemudian hari. Oleh karena itu, perlu adanya suatu program stimulasi yang tepat, sehingga tidak ada tahap perkembangan yang terlewatkan, atau bahkan bila ada yang terlewatkan maka dapat segera diintervensi secara dini.

Program stimulasi yang tepat menuntut pengetahuan dan keterampilan yang komprehensif pada orang dewasa yang terkait dengan anak, sehingga perlu adanya pengembangan program disertai dengan panduan yang dapat digunakan secara praktis di lapangan. Panduan tersebut dapat digunakan oleh pendidik, orangtua atau orang dewasa lain yang terhubung dengan anak, yang pada akhirnya, dapat mengantarkan pertumbuhan dan perkembangan fisik motorik anak secara optimal sesuai dengan usia dan tahap perkembangan anak. Berikut ini disajikan secara ringkas indikator dan program stimulasi yang dapat diberikan kepada bayi, sehingga motorik kasarnya dapat berkembang sesuai dengan usia. Program stimulasi yang diberikan disesuaikan dengan indikator perkembangan motorik kasar pada bayi, dan ketercapaiannya pada setiap anak sangat bervariasi, tergantung dari kondisi awal dan stimulasi yang diberikan, serta nutrisi, pertumbuhan dan kesehatan anak.

\section{Kajian Pustaka}

Di setiap rentang kehidupan, anak umumnya akan mencapai tingkat pertumbuhan dan perkembangan tertentu. Tanda-tanda utama dari pencapaian tumbuh-kembang anak mengacu pada konsep developmental milestones yang melacak kemunculan sejumlah keterampilan (Allen \& Marotz, 2010), seperti keterampilan motor, sosial, emosi, kognitif, bahasa, dan moral. Perkembangan keterampilan tersebut berjalan secara bertahap, umumnya dalam urutan tertentu, sesuai dengan pertambahan usia anak. Khusus pada masa bayi, pertumbuhan dan perkembangan berlangsung lebih cepat dibandingkan dengan anak yang lebih tua. Walaupun terdapat urutan yang bersifat universal dalam perkembangan anak, tetap ditemukan adanya perbedaan individual dari satu anak ke anak yang lain. Ada anak yang berkembang sesuai dengan developmental milestones yang harus dicapainya, namun ada pula yang berkembang lebih cepat atau bahkan lebih lambat. Hal itu menunjukkan bahwa ada faktor-faktor yang mempengaruhi pertumbuhan dan perkembangan.

Perubahan ukuran, bentuk, dan kekuatan otot mendukung perubahan besar pada kemampuan motorik kasarnya. Ketika tubuh bergerak maka akan tertumpu pada tubuh bagian bawah. Sebagai hasilnya, keseimbangan meningkat secara drastis yang membuka jalan untuk perkembangan otot.

Motorik kasar anak akan berkembang sesuai dengan usianya (age appropriateness). Orang dewasa tidak perlu melakukan bantuan terhadap kekuatan otot besar anak. Jika anak telah matang, maka dengan sendirinya anak akan melakukan gerakan yang sudah waktunya untuk dilakukan. Misalnya seorang anak usia 6 bulan belum siap duduk sendiri, maka orang dewasa tidak perlu memaksakan dia duduk di sebuah kursi.

Sistem dalam tubuh berbeda sesuai dengan keunikannya, secara perlahan akan membuat suatu sistem dalam pertumbuhannya. Pertumbuhan fisik sangat dipengaruhi oleh penyerapan gizi yang baik, sedangkan penyerapan gizi didalam tubuh sangat dipengaruhi oleh sistem kelenjar getah bening yang diproduksi oleh tubuh. Seperti kita ketahui bahwa kelenjar getah bening ini tumbuh dengan sangat pesat pada masa bayi dan masa usia dini, kemudian jumlah pertumbuhannya berkurang pada usia remaja. Sistem kelenjar getah bening ini juga membantu melawan infeksi, dengan demikian juga akan membantu menjaga daya tahan tubuh.

Pada masa bayi, pertumbuhan dan perkembangan berlangsung sangat pesat dari bulan ke bulan. Pada aspek fisik-motorik, bayi antara lain mulai dapat menegakkan kepala, membuka-tutup jari-jari tangannya (tidak selalu dikepal), menghisap ASI (Rosen, 1986), dan melihat ke sekeliling (Gober, 2002) pada usia 1 - 3 bulan. Selanjutnya, pada usia $4-6$ bulan, bayi antara lain sudah dapat menegakkan kepala dengan baik, berguling, mulai memasukkan objek ke dalam mulut (Gober, 2002), dan memegang mainan dan botol susu (Gallahue, 1989). Pada usia 7 - 9 bulan, bayi antara lain sudah dapat duduk tanpa bantuan, merangkak, secara aktif menggapai mainan, 
dan memegang benda kecil dengan cara menjumput (Roeber, 2012; Gallahue, 1989). Akhirnya, pada usia 10 - 12 bulan, beberapa keterampilan motorik yang sudah dikuasai baik adalah dapat mengambil mainan yang dijatuhkan, berjalan dengan bantuan (Roeber, 2012), mengambil dan memperhatikan objek, bermain dengan mainan yang didorong, serta melakukan gerakan mengaduk-aduk dengan sendok (Rosen, 1986).

Pada masa toddler ( 1 - 3 tahun) kecepatan pertumbuhan anak sudah mulai menurun. Akan tetapi, kemampuan berbahasa, kognitif, dan sosial berkembang lebih baik. Pada aspek fisik-motorik, anak usia toddler antara lain menunjukkan kemampuan yang lebih baik lagi dalam kemampuan merangkak, seperti merangkak mundur menuruni tangga, berjalan, dan berjingkrak-jingkrak pada usia 12 - 24 bulan. Mereka juga sudah mampu untuk menumpuk balok, membolak-balik halaman buku, membuat coretan-coretan, dan mulai dapat mengontrol buang air kecil pada siang hari pada rentang usia tersebut. Selanjutnya, pada rentang usia 24 - 36 bulan, anak telah mampu menguasai keterampilan seperti mengendarai sepeda roda tiga, menendang bola, melompat di tempat dan memanjat, mulai menggunakan gunting, memakai baju, serta menggunakan sendok tanpa tumpah (Gober, 2002). Pada usia 3 tahun, anak sudah mampu meniru bentuk lingkaran, membuat bentuk dari tanah liat, menggunting, membangun, berdiri seimbang dengan satu kaki, dan melempar bola dengan tujuan sebagai beberapa bentuk pencapaian dalam perkembangan aspek motorik.

Ada berbagai gerakan motorik kasar pada anak usia 0 - 3 tahun, antara lain merayap, merangkak, berdiri, memanjat, berjalan, berlari, menendang, menangkap, melompat, meluncur dan lompat tali. Ketercapaian melakukan berbagai gerakan di atas disebut sebagai pencapaian perkembangan.

Developmental Appropriate Practice (DAP) menyebutkan bahwa perkembangan fisik motorik anak dan koordinasi mata - tangan, mulai bayi hingga sekitar usia 18 bulan sebagai berikut. Pada saat lahir hingga usia 8 bulani, bayi sudah dapat melakukan gerakan reflek yang cukup kompleks, seperti: menari sesuatu untuk diisap, berpegangan ketika akan jatuh, mengubah posisi kepala apabila sulit bernafas, menghindari cahaya terang, bau yang menyengat, dan kesakitan, meletakkan tangan atau benda di dalam mulut, mencoba menggapai benda yang menarik, menggenggam dan melepaskan benda berkali-kali dalam satu waktu, mengangkat kepala dan menahannya, mampu duduk tanpa ada sandaran, berguling, memindahkan dan memainkan benda dengan tangan dan merangkak.

Pada usia 8 - 18 bulan, bayi sudah dapat duduk dengan baik di kursi, menarik badan ke atas, berdiri sambil berpegangan pada perabot, berjalan dengan dituntun ataupun sendiri, melempar benda, menaiki tangga, menggunakan spidol di atas kertas, dan membungkuk, berlari kecil, dan berjalan mundur beberapa langkah

Agar motorik kasar anak mencapai perkembangan optimal, maka pada masa terbukanya jendela kesempatan (windows of opportunity), perlu dilakukan berbagai aktivitas stimulasi. Berbagai aktivitas stimulasi tersebut dapat dilakukan oleh orang dewasa dengan pengetahuan, pengalaman dan keterampilan yang memadai.

\section{METODE PENELITIAN}

Pengembangan program dilakukan pada bulan Februari sampai dengan Juli 2014 dan dilaksanakan pada dua lembaga Taman Penitipan Anak di Kabupaten Mojokerto, Jawa Timur. Sasaran utama kegiatan pengembangan program adalah bayi dengan usia $0-<3$ tahun, yang diberikan stimulasi berupa gerak kasar. Sasaran antara pengembangan program adalah pendidik, pengelola dan orangtua. Teknik penelitian yang digunakan adalah eksperimen semu (quacy experiment) dan tanpa kelompok kontrol. Sasaran penelitian dinilai perkembangan motorik kasarnya antara sebelum dan sesudah diberikan stimulasi gerak kasar.

Instrumen yang digunakan dalam pengembangan program antara lain lembar isian penilaian naskah, lembar obsevasi ketercapaian indikator perkembangan, lembar isian data demografi anak, lembar observasi kemunculan refleks, sensory profile instrument dan lembar observasi ketercapaian indikator perkembangan anak.

Lembar isian penilaian naskah digunakan untuk mendapatkan masukan dari pengguna guna perbaikan untuk penyempurnaan naskah, yang terdiri atas naskah pengembangan program dan panduan stimulasi perkembangan motorik anak usia $0-<12$ bulan, 12 - <24 bulan dan 2 - <3 tahun.

Lembar observasi keterpaian indikator perkembangan digunakan untuk mengetahui indikator perkembangan sebagaimana terdapat dalam panduan stimulasi perkembangan motorik kasar yang belum tercapai, sehingga perlu dilakukan pengulangan kegiatan. 
Lembar isian demografi anak digunakan untuk mendapatkan data mengenai profil anak secara menyeluruh, sehingga apabila terdapat keterlambatan atau penyimpangan dalam perkembangan motorik kasar, dapat diketahui penyebabnya dan dilakukan intervensi dini, sehingga anak dapat berkembang sesuai dengan usia.

Lembar observasi refleks anak digunakan terutama untuk mengetahui kemungkinan masih adanya refleks primitif yang masih muncul pada bayi atau anak, sehingga perlu dilakukan stimulasi yang tepat untuk menghilangkan refleks yang dapat mempengaruhi perkembangan motorik kasar atau perkembangan pada aspek lainnya.

Sensory profile instrument digunakan untuk mengetahui profil perkembangan sensori anak (auditori, taktil, vestibuler, indera perasa, visual) sehingga dapat dilakukan intervensi sehingga anak dapat berkembang sesuai dengan usianya.

Lembar observasi pencapaian indikator perkembangan motorik kasar bayi usia $0-<12$ bulan digunakan untuk mengamati indikator yang sudah dan belum tercapai, sehingga dapat dirancang kegiatan stimulasi selanjutnya.

Prosedur pengembangan program pada dasarnya terdiri atas studi pendahuluan (pre-liminary study), pengembangan bahan-bahan pendukung pengembangan program, validasi naskah, uji coba lapangan, penyempurnaan naskah pengembangan program dan sosialisasi program.

\section{HASIL DAN PEMBAHASAN}

\section{Hasil Pengembangan Program}

1. Karakteristik bayi

Sebagian besar adalah anak pertama (50\%), kemudian anak kedua sebesar $40 \%$ dan hanya $10 \%$ yang merupakan anak terakhir. Urutan kelahiran biasanya berpengaruh terhadap pola pengasuhan orangtua, yang pada akhirnya dapat mempengaruhi pertumbuhan dan perkembangan anak selanjutnya. Anak dengan urutan kelahiran pertama biasanya mendapatkan perhatian yang lebih banyak dari orangtua, karena orangtua memiliki harapan yang besar terhadapnya. Perhatian tersebut dapat berupa curahan kasih sayang yang berlebih, limpahan sumber daya keluarga yang besar, perlindungan yang kadang berlebihan (over protection), dan sebagainya, yang akan mempengaruhi pertumbuhan dan perkembangan anak.

Hal ini belum lagi apabila dikaitkan dengan struktur keluarga, pada keluarga besar, anak dengan urutan kelahiran pertama biasanya mendapatkan curahan kasih sayang dari banyak anggota keluarga, namun hal ini dapat berpengaruh kurang baik terhadap perkembangan anak selanjutnya, karena stimulasi yang diterima anak bisa berlebihan (overstimulation). Pada keluarga inti, kedua orangtua juga memiliki fokus yang besar terhadap pertumbuhan dan perkembangan anak, dibandingkan pada anak dengan urutan kelahiran selanjutnya.

Urutan kelahiran anak juga dapat berpengaruh pada kepribadian.Karena anak pertama cenderung mendapatkan kasih sayang, perhatian dan hal-hal lainnya secara penuh selama kira-kira beberapa tahun, maka biasanya memiliki prestasi akademis yang lebih tinggi apabila dibandingkan dengan adikadiknya dan memiliki kesempatan untuk maju lebih awal. Akan tetapi, ia juga merasakan tanggung jawab dan tekanan yang berat karena biasanya orangtua memberikan tuntutan lebih. Hal ini akan membuatnya menjadi anak yang lebih mudah cemas apabila dibandingkan dengan adik-adiknya. Anak kedua biasanya memilih gaya hidup alternatif daripada harus bersaing dengan kakaknya. Akan tetapi, anak kedua biasanya menyerap banyak informasi dari kakaknya. Dalam hal aktivitas, anak kedua biasanya memilih aktivitas yang lebih kreatif, karena aktivitas ini memungkinkannya mengekspresikan keunikan diri sekaligus seringkali menantang peraturan yang ditetapkan oleh orangtuanya (Woolfson, 2005).

\section{Profil Kesehatan Bayi}

Sebagian bayi mengalami permasalahan kesehatan serta pertumbuhan dan perkembangannya, baik saat berada dalam kandungan (pre-natal), persalinan (ante-natal), maupun ketika sudah dilahirkan (post natal).

\section{Profil Sensori Bayi}

Hasil penelitian menunjukkan bahwa terdapat perbedaan profil sensory bayi antara sebelum dan sesudah diberi stimulasi gerak. Hal ini terlihat dari tabel di atas bahwa nilai $p$ atau sig. (2-tailed)<0.05, yang berarti $\mathrm{HO}$ ditolak (ada perbedaan sensory profile antara sebelum dan sesudah dilakukan stimulasi).

\section{Profil Perkembangan Refleks Bayi}

Profil perkembangan refleks bayi pada umumnya tidak berjalan normal. Sebagian besar refleks belum menghilang pada waktunya, yang dikahwatirkan akan mempengaruhi perkembangan keseimbangan dan koordinasi anak selanjutnya. Refleks yang belum menghilang antara lain : (a) asymetric Tonic Neck Reflex (ATNR) distimulasi saat kepala bayi berputar 
dan membuat lengan menekuk sehingga lengan sisi berlawanan akan meregang. Refleks ini membantu mendorong bayi turun di jalan lahir dan semakin kuat selama proses kelahiran. Setelah lahir, refleks ini meyakinkan jalan nafas terbuka dan koordinasi antara mata dan lengan berkembang. Retensi akan menghambat perkembangan merangkak dan kemudian keseimbangan, kemampuan menulis, gerak independen lengan dan kaki, serta kesulitan gerak lateralitas atau gerak yang searah; (b) Symetric Tonic Neck Reflex (STNR) membantu bayi mencapai posisi tengkurap dan merangkak. Retensi membuat bayi merangkak dengan perut, atau merangkak dengan gerakan 2 lengan bersama, atau cenderung menarik tubuh untuk berdiri dan berjalan. Tanda retensi juga nampak saat duduk melantai akan meletakkan kaki membentuk "W", kelemahan koordinasi mata-tangan, lambat saat menyalin tulisan di papan tulis ke buku serta kesulitan pada saat belajar berenang; (c) spinal galant reflex merupakan refleks penting saat proses kelahiran. Titik penting refleks ini berada di tulang belakang antara panggul ke area punggung. Saat stimulasi sendi panggul akan berputar, lutut dan tangan menekuk, kepala terangkat, bayi berputar sepanjang jalan lahir. Refleks ini juga berperan dalam perkembangan gerak merangkak. Retensi berhubungan dengan kegelisahan saat duduk, mengompol, melangkah yang tak seimbang, tidak menyukai pakaian ketat sekitar pinggang, konsentrasi buruk disertai gangguan memori jangka pendek; (d) refleks yang diaktifkan untuk menggenggam. Efek retensi sangat mengganggu kemampuan jemari, menulis, artikulasi, gerak bibir saat menulis, untuk refleks plantar mengganggu kemampuan berjalan.

\section{Profil Pencapaian Indikator Perkembangan Motorik Kasar}

Perkembangan motorik kasar berdasarkan pada indikator yang telah disusun untuk bayi usia 0 $<12$ bulan berdasarkan pada pengamatan setiap kali kegiatan, didapatkan beberapa indikator yang belum tercapai hingga minggu keempat. Beberapa indikator yang belum tercapai antara lain mampu berjalan $2-3$ langkah, mampu memungut 2 benda, masing-masing tangan memegang 1 benda, mampu bermain tepuk tangan, mampu bermain kepala, mampu bermain bahu, dan mampu mengangkat benda ke posisi berdiri. Indikator tersebut belum tercapai karena selama ini lembaga PAUD jarang atau bahkan belum pernah melakukan stimulasi untuk mencapai indikator tersebut, sehingga merupakan hal yang cukup baru bagi anak, dan memerlukan pengulangan yang lebih intensif, sehingga anak dapat melakukan.

\section{Pembahasan}

A. Indikator Perkembangan Motorik Kasar Bayi Usia

$$
0-<12 \text { Bulan }
$$

Indikator perkembangan motorik kasar pada bayi merupakan salah satu pedoman yang dapat digunakan untuk merancang program stimulasi. Di samping itu, juga dapat digunakan sebagai acuan untuk mengetahui kesesuaian perkembangan motorik kasar dengan usia, sehingga dapat ditemukan kemungkinan adanya penyimpangan atau keterlambatan. Penyimpangan atau keterlambatan dalam perkembangan fisik motorik dapat berakibat pada rendahnya partisipasi anak dalam permainan dengan teman sebaya, penurunan kompetensi sosial dan rendahnya rasa percaya diri. Lebih jauh, latihan dan pengembangan kemampuan motorik sangat mendukung kesehatan fisik dan mental (Barbara, 2012:487).

Berikut ini disajikan indikator perkembangan motorik kasar bayi usia 0 - <12 bulan, yang merupakan sintesis dari berbagai kajian, antara lain Peraturan Menteri Pendidikan Nasional No. 58 tahun 2009 tentang Standar PAUD, kajian neurosains tentang perkembangan bayi usia 0 - <12 bulan, serta penelitian di lapangan yang dikembangkan oleh BPPAUDNI Regional II Surabaya pada tahun 2014. Indikator berikut ini mungkin saja mengalami perkembangan dan penyempurnaan, sesuai dengan kondisi perkembangan anak Indonesia secara umum.

Tabel 1. Indikator Perkembangan Motorik Kasar Bayi Usia $0-<12$ Bulan

\begin{tabular}{|c|c|c|}
\hline \multirow{3}{*}{1.} & \multirow{3}{*}{$0-<3$ Bulan } & $\begin{array}{l}\text { Melakukan gerakan menoleh ke kanan/ } \\
\text { kiri atau sebaliknya }\end{array}$ \\
\hline & & $\begin{array}{l}\text { Mengangkat kepala setinggi } 45 \text { derajat } \\
\text { pada posisi tengkurap }\end{array}$ \\
\hline & & $\begin{array}{l}\text { Menggerakkan kepala dari kiri ke tengah, } \\
\text { dari tengah ke kanan atau sebaliknya pada } \\
\text { posisi tengkurap, telentang atau digen- } \\
\text { dong }\end{array}$ \\
\hline \multirow[b]{3}{*}{2.} & \multirow[b]{3}{*}{$3-<6$ Bulan } & Mampu merayap \\
\hline & & Mampu merangkak \\
\hline & & $\begin{array}{l}\text { Dapat menjaga keseimbangan pada } 3 \\
\text { titik tumpu, yang merupakan tantangan } \\
\text { keseimbangan kesiapan duduk ( } 1 \text { lengan } 2 \\
\text { tungkai atau } 2 \text { lengan } 1 \text { tungkai) }\end{array}$ \\
\hline \multirow{5}{*}{3.} & \multirow{5}{*}{$6-<9$ Bulan } & Mampu duduk \\
\hline & & $\begin{array}{l}\text { Mampu merangkak meraih mainan atau } \\
\text { mendekati seseorang }\end{array}$ \\
\hline & & $\begin{array}{l}\text { Mampu mengangkat diri, bertumpu pada } \\
\text { dua kaki (bipedal), berjalan merambat } \\
\text { pada benda (meja, kursi, atau benda lain } \\
\text { yang aman) }\end{array}$ \\
\hline & & $\begin{array}{l}\text { Mampu memindahkan benda dari satu } \\
\text { tangan ke tangan lainnya }\end{array}$ \\
\hline & & Mampu berjalan 2 - 3 langkah \\
\hline
\end{tabular}

Jurnal IImiah VISI P2TK PAUD NI - Vol. 9, No.1, Juni 2014 


\begin{tabular}{|c|c|c|}
\hline & & $\begin{array}{l}\text { Mampu memungut } 2 \text { benda, masing-ma- } \\
\text { sing tangan pegang } 1 \text { benda }\end{array}$ \\
\hline & & $\begin{array}{l}\text { Mampu memungut } 2 \text { benda, masing-ma- } \\
\text { sing tangan pegang } 1 \text { benda }\end{array}$ \\
\hline & & $\begin{array}{l}\text { Mampu memungut benda kecil sebesar } \\
\text { kacang dengan cara meraup }\end{array}$ \\
\hline & & $\begin{array}{l}\text { Mampu memindahkan benda dari satu } \\
\text { tangan ke tangan lainnya }\end{array}$ \\
\hline & & $\begin{array}{l}\text { Mampu memungut } 2 \text { benda, masing-ma- } \\
\text { sing tangan memegang } 1 \text { benda }\end{array}$ \\
\hline & & $\begin{array}{l}\text { Mampu memungut benda kecil sebesar } \\
\text { kacang dengan cara meraup }\end{array}$ \\
\hline & & $\begin{array}{l}\text { Mampu mencari benda atau mainan yang } \\
\text { dijatuhkan }\end{array}$ \\
\hline & & Mampu bermain tepuk tangan \\
\hline & & Mampu bermain kepala \\
\hline & & Mampu bermain bahu \\
\hline \multirow{5}{*}{4.} & \multirow{5}{*}{$\begin{array}{l}9-<12 \\
\text { Bulan }\end{array}$} & $\begin{array}{l}\text { Mampu mengangkat benda ke posisi } \\
\text { berdiri }\end{array}$ \\
\hline & & $\begin{array}{l}\text { Mampu belajar berdiri dengan berpega- } \\
\text { ngan di kursi, meja atau benda lain yang } \\
\text { aman dan kuat }\end{array}$ \\
\hline & & $\begin{array}{l}\text { Mampu melakukan gerakan lengan } \\
\text { mengayun mengambil obyek (menyekop, } \\
\text { mendayung, mencangkul) dengan dua } \\
\text { lengan }\end{array}$ \\
\hline & & $\begin{array}{l}\text { Mampu menggerakan bahu pada ruang } \\
\text { gerak sendi maksimal }\end{array}$ \\
\hline & & $\begin{array}{l}\text { Mampu melakukan gerakan memukul } \\
\text { berirama }\end{array}$ \\
\hline
\end{tabular}

Sumber : Pengembangan Program Stimulasi Perkembangan Motorik Kasar Anak Usia 0 - <3 Tahun, BPPAUDNI Regional II Surabaya, 2014

Indikator di atas juga merupakan salah satu dasar untuk merancang gerak stimulasi bagi bayi, sehingga dapat mencapai perkembangan motorik kasar sesuai dengan usia dan karakteristik anak secara optimal.

\section{B. Pedoman Stimulasi Bayi Usia 0 - <12 Bulan}

Untuk melakukan stimulasi bayi, perlu pemahaman yang komprehensif mengenai karakteristik, usia, tahap pertumbuhan dan perkembangan bayi. Secara umum, pedoman yang perlu diperhatikan sebagai berikut. Pertama, pastikan bahwa stimulasi sesuai dengan rentang usia bayi (rentang $0-<3$ bulan, $3-<6$ bulan, $6-<9$ bulan dan $9-<12$ bulan), sehingga sesuai dengan kealamiahan perkembangan motorik kasar anak. Dengan demikian, anak bisa mencapainya secara optimal, dan tidak ada upaya pemaksaan yang justru mengganggu proses pertumbuhan dan perkembangan anak. Kedua, pastikan bahwa bayi dalam kondisi sehat, sehingga stimulasi yang diberikan dapat optimal dan tidak membahayakan kesehatan bayi dan dilakukan pada kondisi lingkungan aman, bersih dan nyaman.

Pemberi stimulasi (pendidik, orangtua atau orang dewasa lainnya) juga hendaknya dalam kondisi bersih dan tidak sedang menderita penyakit menular. Apabila pemberi stimulasi dalam kondisi tidak sehat, pastikan sedang dalam proses pengobatan dan lindungi bayi dari kemungkinan tertular penyakit, misalnya dengan menggunakan masker atau alat pelindung lainnya yang mencegah proses penularan penyakit. Di samping itu, pemberi stimulasi sebaiknya berlatih terlebih dahulu sebelum melakukannya bersama bayi, sehingga program stimulasi yang dilakukan tepat, sesuai dengan panduan karena pemberi stimulasi dapat melakukan dengan benar. Apabila merasa kurang memahami, mintalah didampingi oleh ahli, seperti petugas kesehatan (dokter, bidan, perawat, dan lainlain), pendidik PAUD atau kader yang terlatih.

Ketiga, hendaknya dipastikan bahwa bayi nyaman untuk melakukan kegiatan tersebut dan menghentikan program stimulasi apabila bayi tampak mulai tidak nyaman. Program stimulasi dilakukan dengan penuh kesabaran dan bertahap, karena bayi berkembang secara bertahap dan setiap bayi adalah unik, sehingga proses stimulasi setiap bayi akan bervariasi, baik dari sisi ketercapaian maupun irama dan kecepatannya. Apabila menggunakan peralatan dalam melakukan stimulasi, pastikan bahwa peralatan tersebut aman bagi bayi. Apabila peralatan yang digunakan cukup kecil, maka lakukan pengawasan dengan baik, sehingga tidak membahayakan keselamatan dan kesehatan bayi. Seluruh stimulasi dilakukan sesering mungkin untuk membentuk kebiasaan (habituasi) dengan pola yang berulang. Hasil dari kegiatan stimulasi tidak bersifat cepat (instant), karena anak berkembang secara bertahap dengan irama perkembangan yang berbeda-beda.

C. Ragam Stimulasi Gerak untuk Mengoptimalkan Perkembangan Motorik Kasar Bayi Usia 0 - <12 Bulan

Untuk menstimulasi kematangan motorik diperlukan sentuhan, kontak langsung, permainan dengan alat main yang berwarna terang serta dapat dimanipulasi, dan rangsangan yang dapat menimbulkan gerak. Yang sangat penting dalam perkembangan motorik bayi adalah semakin meningkatkan independensi yang dimiliki oleh bayi, sehingga bayi semakin dapat menjelajahi lingkungan secara luas serta menunjukkan kemampuan interaksi sosial yang semakin meningkat sesuai dengan usia perkembangannya.

Stimulasi motorik kasar diperlukan secara tepat, sehingga bayi dapat berkembang dengan baik dan menyiapkan bayi menuju pada kegiatan pembelajaran yang lebih kompleks. Stimulasi diberikan secara bertahap sesuai dengan usia dan karakteristik anak.

Pada bayi usia $0-<12$ bulan, stimulasi diberi- 
kan berdasarkan pada 4 kelompok usia, yaitu $0-<3$ bulan, $3-<6$ bulan, $6-<9$ bulan, dan $9-<12$ bulan. Pengelompokan tersebut didasarkan pada Peraturan Menteri Pendidikan Nasional (Permendiknas) No. 58 tahun 2009 tentang Standar Pendidikan Anak Usia Dini.

\section{Bayi Usia $0-<3$ bulan}

Bayi yang baru lahir tidak sepenuhnya tak berdaya. Hal yang menunjukkan hal tersebut antara lain adanya beberapa refleks dasar (Pedroso, 2008, dalam Santrock, 1995:207). Bayi tidak akan berlari, melompat atau bahkan duduk pada usia ini. Akan tetapi, bagaimanapun juga, motorik kasar bayi sedang berkembang, termasuk didalamnya adalah mereka akan berusaha menggerakkan kepala, leher, lengan dan kaki. Ketika ditengkurapkan, kepala bayi akan berusaha memutar dari satu sisi ke sisi yang lainnya, lengan berusaha bergeser, dan akan mencoba menggerakkan atau menendangkan kaki. Bayi juga akan berusaha mengangkat kepala. Pada usia sekitar 3 bulan, bayi akan memiliki kontrol yang lebih besar terhadap kepala, lengan, dan kaki.

Di samping itu, keterampilan motorik membutuhkan usaha yang aktif untuk melakukan koordinasi. Pada akhirnya, perkembangan tersebut terkait dengan perkembangan sistem saraf, sifat fisik dan kemungkinan untuk timbulnya gerakan, serta tujuan yang membuat bayi termotivasi untuk melakukannya.

Oleh karena itu, pada dasarnya, tujuan melakukan stimulasi pada bayi usia $0-<3$ bulan antara lain menekan kekakuan otot karena refleks primitif pada gerak di tengkuk untuk membangun koordinasi gerak kepala-leher-bahu, meningkatkan kemampuan untuk otot leher untuk meregang dan memendek (kontraksi), membantu bayi mengenal arah dan posisi untuk berguling, memberi rangsangan agar bayi dapat menggerakkan kepala dari kiri ke tengah, dari tengah ke kanan atau sebaliknya untuk menekan refleks primitif ATNR agar anak di kemudian hari tidak memiliki hambatan untuk menulis dan membaca, mendapatkan fleksibilitas gerakan leher yang akan menekan kekakuan otot dari refleks ATNR (Asimetrical Tonic Neck Reflex) dan STNR (Simetrical Tonic Neck Reflex) untuk menjadi TLR (Tonic Labirin Reflex). TLR merupakan stimulasi persiapan menegakkan tubuh. Untuk tubuh bagian atas gerak stimulasi bertujuan mendukung stimulus untuk menekan refleks ATNR. Untuk tubuh bagian bawah, gerak stimulasi bertujuan untuk menekan refleks spinal gallant agar anak nanti mampu mengelola gerakan tungkai sesuai dengan ruang gerak optimal sendi paha dan menghambat kontraksi kantung kencing di luar kendali (agar anak tidak mengompol)
Dengan demikian, gerak stimulasi untuk bayi usia 0 - <3 bulan bertujuan untuk membantu bayi mengenal arah dan posisi untuk berguling, mendapatkan fleksibilitas gerakan leher yang akan menekan kekakuan otot dari refleks ATNR (Asimetrical Tonic Neck Reflex) dan STNR (Simetrical Tonic Neck Reflex) untuk menjadi TLR (Tonic Labirin Reflex). TLR merupakan stimulasi persiapan menegakkan tubuh dan mematangkan kemampuan berguling, telentang menuju tengkurap.

Terkait dengan tujuan stimulasi dan gerak stimulasi, maka terdapat beragam gerak stimulasi yang dapat diberikan kepada bayi pada usia $0-<3$ bulan, antara lain agar bayi dapat melakukan gerakan menoleh ke kanan dan kiri, lalu dapat mengangkat kepala setinggi 45 derajat, maka gerak stimulasi yang dapat dilakukan adalah menengkurapkan bayi, berbicara dengan getaran suara di leher (lembut) - tidak dengan suara melengking - di sisi kiri/kanan bayi secara bergantian agar bayi menoleh ke kanan atau ke kiri dengan menggerakkan leher, sehingga bayi mendapatkan fleksibilitas gerakan leher yang akan menekan kekakuan otot dari refleks ATNR (Asimetrical Tonic Neck Reflex) dan STNR (Simetrical Tonic Neck Reflex) untuk menjadi TLR (Tonic Labirin Reflex). TLR merupakan stimulasi persiapan menegakkan tubuh. Di sisi lain, memegang pergelangan kaki bayi, menggerakkan ke arah perut bergantian dengan posisi menyilang. Pada saat tersebut, lutut kanan ke arah perut kiri, lutut kiri ke arah perut kanan. Posisi lengan anak disilangkan ke kanan/kiri secara bergantian, sehingga tubuh bagian atas mengikuti). Tungkai disilangkan bergantian ke kanan/kiri. Gerak stimulasi diberikan kepada bayi untuk mematangkan kemampuan berguling, telentang dan menuju tengkurap.

Yang perlu diperhatikan stimulasi dalam memberikan gerak antara lain gerakan kepala bayi terjadi secara alamiah, buka digerakkan oleh orang dewasa atau paksaan dari luar, bayi dapat diberi salah satu rangsangan auditori, visual atau taktil (sentuhan/ perabaan) untuk menstimulasi bayi untuk menggerakkan kepala dan rangsangan auditori, visual atau taktil hendaknya tidak dilakukan secara bersamaan untuk mengembangkan kemampuan atensi (perhatian), fokus dan konsentrasi

\section{E. Bayi Usia 3 - <6 bulan}

Pada usia 3 bulan, bayi dapat mempertemukan kedua tangannya bersama-sama. Pada usia 6 bulan, bayi akan berusaha mendorong tubuhnya untuk duduk ketika sedang tengkurap. Oleh karena itu, tujuan gerak stimulasi yang diberikan antara lain merangsang refleks TLR menuju koordinasi lengan dan tungkai 
untuk menemukan keseimbangan dan awal kemampuan anti gravitasi, mampu mengendalikan kontraksi otot-otot lengan dan tungkai, merangsang fungsi vestibular (keseimbangan) mencapai keseimbangan untuk menyiapkan anak agar memiliki kendali gerak (tidak hiperaktif), menguatkan refleks TLR dan anti gravitasi untuk menemukan keseimbangan dalam gerak, membangun koordinasi pada fungsi otak kiri dan kanan yang memperkuat fungsi corpus collosum (jembatan antara otak kiri dan kanan), merangsang fungsi vestibular (keseimbangan) agar anak tidak hiperaktif yaitu bahwa anak merasa bergerak adalah seimbang, demikian sebaliknya dan mampu mengenali anti gravitasi.

Dengan demikian, tujuan gerak stimulasi yang diberikan antara lain mampu mengendalikan kontraksi otot-otot lengan dan tungkai, merangsang fungsi vestibular (keseimbangan) mencapai keseimbangan untuk menyiapkan anak agar memiliki kendali gerak (tidak hiperaktif), mampu bergerak dengan posisi tubuh tidak menempel landasan, memiliki rangkaian gerak atau koordinasi lengan tungkai homolateral hingga kontralateral, menguatkan otot lengan, tungkai, perut dan punggung dan merangsang kemampuan kontraksi otot tungkai untuk melakukan gerakan mendorong

Beberapa hal yang perlu diperhatikan pada saat memberikan stimulasi pada bayi di usia ini antara lain bayi tidak perlu menggunakan alas kaki pada saat dilakukan stimulasi untuk menstimulus indera taktil, bila cuaca dingin, bayi hendaknya menggunakan kaos kaki yang alasnya berbintik karet, bila anak bertumpu pada empat titik (lengan dan tungkai) serta menggunakan tambahan tumpuan dengan area jemari kaki, posisi ini akan mengakibatkan saat satu lengan diangkat, anak mendorong tubuh ke depan dengan bantuan daya dorong jemari kaki. Hal tersebut menunjukkan kegagalan otot pada area paha dan pantat untuk menahan tumpuan dan menggerakkan tubuh ke arah yang diinginkan.

Terkait dengan tujuan stimulasi dan gerak stimulasi, maka gerak stimulasi yang dapat diberikan pada bayi usia ini antara lain merangsang refleks TLR menuju koordinasi lengan dan tungkai untuk menemukan keseimbangan dan awal kemampuan anti gravitasi dengan menaruh benda di depan bayi, sehingga bayi akan berusaha menjangkau, merangsang anak untuk merangkak dengan cara berada di depan anak sambil menarik mainan agar anak merangkak menghampiri mainan, dan meletakkan benda yang dijauhkan sedikit demi sedikit agar bayi dapat menjaga keseimbangan pada 3 titik tumpu, yang merupakan tantangan keseimbangan kesiapan duduk (1 lengan 2 tungkai atau
2 lengan 1 tungkai).

F. Bayi Usia $6-<9$ bulan

Mendekati usia 8 bulan, terdapat kemajuan pesat pada perkembangan motorik bayi, yaitu dari posisi duduk dengan dukungan kedua tangannya menjadi duduk dengan tanpa bantuan. Pada usia 8 bulan, bayi akan berusaha berpindah tempat. Sesungguhnya, usia ini merupakan usia persiapan bagi bayi untuk dapat berdiri tegak dengan menggunakan kedua kakinya (bipedal). Terdapat urutan gerakan pada bayi mulai merayap hingga berdiri, yaitu diawali dengan kemampuan menggerakkan tubuh secara homologus, yaitu menggerakkan satu sisi tubuh. Hal yang selanjutnya terjadi adalah mengangkat tubuh yang merupakan gerakan anti gravitasi (kemampuan tubuh untuk melawan daya tarik/gravitasi bumi agar tidak jatuh). Selanjutnya, bayi dapat melakukan gerakan homolateral (gerakan searah), kemudian duduk, melakukan gerakan kontralateral (gerakan silang) dan menggunakan kedua kaki (bipedal).

Oleh karena itu, tujuan pemberian stimulasi antara lain merangsang refleks postural dengan menekan refleks TLR, kematangan refleks postural dengan menekan refleks TLR dan spinal gallant, meningkatkan refleks postural menuju refleks integrasi, merangsang center of gravity (titik keseimbangan tubuh pada garis poros tubuh pada gravitasi), mengenal base of support dan proprioseptik, membangun koordinasi pada fungsi otak kiri dan otak kanan sehingga memperkuat fungsi corpus collosum, merangsang kendali pada bagian-bagian lengan sebagai persiapan untuk kegiatan menulis, membangun kemampuan pada saat transisi motorik kasar menuju motorik halus melalui peningkatan kontraksi otot lengan bawah, meningkatkan sensitivitas telapak tangan dengan pengendalian jemari, meningkatkan koordinasi mata dan tangan dalam pengembangan kemampuan spasial, merangsang visual imajinasi, awal identifikasi obyek dan fokus. Dengan demikian, kemudian bayi dapat menggerakkan kedua tangannya untuk bertepuk tangan. Pada akhirnya, merangsang kematangan visual imajinasi dan mirroring (bayi menirukan gerakan orang dewasa seperti kegiatan bercermin), menyiapkan anak untuk mengembangkan kemampuan motorik halus pada jari jemari tangan dan menyiapkan anak mencapai kelenturan bahu dan lengan untuk mengembangkan kemampuan motorik halus pada jari jemari tangan.

Pada dasarnya, tujuan gerak stimulasi yang dilakukan adalah agar bayi dapat duduk dengan posisi yang benar, merangsang fungsi vestibular (keseimbangan) agar anak tidak hiperaktif yaitu bahwa anak merasa bergerak adalah seimbang, demikian 
sebaliknya, bayi dapat mengenali perintah, menguatkan otot, membantu merangsang pertumbuhan tulang, membantu mengendalikan otot-otot di saluran kencing dan sekitarnya agar anak tidak mengompol, merangsang fungsi vestibular (keseimbangan) agar anak memiliki kendali gerak (tidak hiperaktif). Ketika hal-hal tersebut terstimulasi, maka bayi akan mampu mengenali anti gravitasi, mampu mengenali arah, sebagai stimulus membangun kecerdasan visual spasial, menguatkan otot lengan, tungkai, punggung dan perut, membangun kepercayaan diri anak, merangsang fungsi vestibular (keseimbangan) agar anak memiliki kendali gerak (tidak hiperaktif), mampu mengenali anti gravitasi, bayi dapat memindahkan benda dari satu tangan ke tangan lainnya, merangsang fungsi vestibular (keseimbangan) agar anak memiliki kendali gerak (tidak hiperaktif).

Di sisi lain, gerak stimulasi juga meningkatkan kemampuan bayi untuk mengenali bobot benda dari stimulus proprioseptik (rangkaian gerak sendi). Hal ini menjadi dasar perkembangan pengetahuan konsep matematis dan kemampuan untuk membangun koordinasi pada fungsi otak kiri dan otak kanan sehingga memperkuat fungsi corpus collosum. Hal ini terjadi karena gerak stimulasi akan merangsang fungsi vestibular (keseimbangan) agar anak memiliki kendali gerak (tidak hiperaktif), atensi (perhatian), fokus dan konsentrasi, kemampuan untuk mengukur jarak dan mengendalikan arah gerak tubuh, kontrol gerakan tubuh dan kemampuan koordinasi visual, sehingga bayi mampu mengenali anti gravitasi. Dengan latihan yang berulang-ulang, maka gerak stimulasi juga dapat membangun kecerdasan visual spasial bayi, melatih koordinasi antara kedua tangan, menguatkan otot-otot tangan, melatih bayi untuk menggerakkan kepala dan bahu.

Berdasarkan pada tujuan stimulasi dan gerak stimulasi, maka ragam gerak stimulasi yang dapat diberikan antara lain meletakkan benda yang dijauhkan sedikit demi sedikit untuk merangsang refleks postural dengan menekan refleks TLR, mengajak bayi merangkak mengambil benda untuk meningkatkan kematangan refleks postural dengan menekan refleks TLR dan spinal gallant, mengajak anak mengambil benda benda yang lebih tinggi dari kepala, yang berada pada posisi dimana terdapat tempat untuk anak berpegangan jika ia kehilangan keseimbangan yang bertujuan untuk Meningkatkan refleks postural menuju refleks integrasi.

Di samping itu, dapat juga dengan cara memberikan alat yang berupa pegangan kokoh yang dapat digunakan untuk merambat pegangan sambil berjalan sendiri, tetapi bukan dipegangi oleh orang dewasa. Stimulasi yang lain seperti memindahkan benda dari satu tangan ke tangan lainnya dengan tujuan membangun koordinasi pada fungsi otak kiri dan otak kanan sehingga memperkuat fungsi corpus collosum, memungut 2 benda, masing-masing tangan pegang 1 benda dengan tujuan merangsang kendali pada bagian-bagian lengan sebagai persiapan untuk kegiatan menulis. Kegiatan ini dimasudkan sebagai transisi dari kemampuan motorik kasar ke motorik halus. Indikator ini dapat dicapai ketika anak sudah dalam posisi duduk, memungut benda kecil sebesar kacang dengan cara meraup, dengan tujuan Transisi motorik kasar menuju motorik halus melalui peningkatan kontraksi otot lengan bawah, meningkatkan sensitivitas telapak tangan dengan pengendalian jemari dan meningkatkan koordinasi mata dan tangan dalam pengembangan kemampuan spasial, mencari benda atau mainan yang dijatuhkan dengan tujuan merangsang visual imajinasi, awal identifikasi obyek dan fokus, bermain tepuk tangan, bermain kepala untuk merangsang kematangan visual imajinasi dan mirroring (bayi menirukan gerakan orang dewasa seperti kegiatan bercermin) dan bermain bahu merupakan stimulus untuk persiapan motorik halus.

G. Bayi Usia $9-<12$ bulan

Bayi akan mulai berguling dan berusaha mengangkat dan menarik tubuhnya, berpegangan pada benda-benda seperti meja, kursi, untuk mulai belajar berdiri. Dengan demikian, bayi dapat berpindah dari duduk ke berdiri dan duduk sendiri beberapa saat. Selama waktu-waktu ini, anak mengalami kemajuan gerak, dari berguling ke berdiri sendiri dan kadangkadang ada yang sudah mulai berjalan pada usia sekitar $10-12$ bulan.

Tujuan pemberian stimulasi pada usia ini antara lain melatih koordinasi anggota tubuh bayi, keseimbangan, kekuatan otot lengan dan tungkai, visual dan spasial bayi, proprioseptik, koordinasi, keseimbangan, kekuatan otot perut, punggung dan tungkai, serta visual dan spasial bayi. Dengan demikian, tujuan gerak stimulasi antara lain agar bayi mampu mengkoordinasikan anggota tubuhnya untuk mengangkat benda yang memiliki berat (bobot) dan mengangkat tubuhnya dan berdiri secara seimbang sendiri atau berpegangan

Berdasarkan pada tujuan stimulasi dan gerak stimulasi, maka ragam gerak yang dapat dilatihkan pada bayi antara lain mengangkat benda ringan dari posisi jongkok ke posisi berdiri, dengan tujuan melatih koordinasi anggota tubuh bayi, keseimbangan, kekuatan otot lengan dan tungkai, visual dan spasial bayi dan proprioseptik, dan berdiri dengan berpegangan 
pada benda (misalnya kursi, meja, tempat tidur), sehingga bayi dapat mengangkat tubuhnya dan berdiri secara seimbang sendiri atau berpegangan. Anak sebaiknya menemukan sendiri keseimbangan, karena ketika hal ini terjadi, maka anak memiliki kecerdasan spasial (ruang). Kecerdasan spasial pada saat ini semakin diperlukan, mengingat lahan gerak yang semakin sempit.

Hal yang perlu diperhatikan adalah apabila anak berpegangan pada tangan orang dewasa, maka titik tumpu pindah ke pegangan. Kita perlu berhatihati karena bisa menyebabkan timbulnya gangguan keseimbangan pada organ vestibular yang dapat menyebabkan gangguan kendali gerak (mirip hiperaktif). Anak sebaiknya menemukan sendiri keseimbangan, karena ketika hal ini terjadi, maka anak memiliki kecerdasan spasial (ruang). Kecerdasan spasial pada saat ini semakin diperlukan, mengingat lahan gerak yang semakin sempit.

Pada dasarnya, ragam gerak stimulasi untuk bayi usia $0-<12$ bulan sebagaimana tersebut di atas, dapat dikembangkan oleh orang dewasa yang berinteraksi dengan bayi, sesuai dengan indikator pencapaian perkembangan dan kondisi bayi. Yang perlu diperhatikan adalah bahwa ragam gerak stimulasi tidak bertujuan mempercepat perkembangan bayi, tetapi membantu bayi mencapai perkembangan motorik kasarnya secara optimal, yang sangat berguna kelak di kemudian hari.

\section{KESIMPULAN}

\section{Kesimpulan}

Perkembangan motorik kasar bayi usia $0-<12$ bulan yang mendapatkan stimulasi mengalami perbaikan dan terjadi dalam waktu yang sangat singkat. Permasalahan dalam stimulasi perkembangan motorik kasar anak usia $0-<12$ bulan antara lain riwayat kesehatan bayi pada saat berada dalam kandungan, persalinan maupun pasca persalinan dan urangnya stimulasi perkembangan motorik kasar yang terutama dilakukan oleh orangtua karena kekurangpahaman orangtua mengenai pentingnya hal tersebut dan cara untuk melakukan stimulasi

Beberapa indikator perkembangan motorik kasar belum tercapai hingga akhir uji coba pengembangan program karena setiap anak memiliki irama dan kecepatan dalam perkembangan yang berbedabeda, sehingga perlu dilanjutkan oleh pendidik, orangtua atau orang dewasa lainnya yang berinteraksi dengan anak

\section{Saran}

Saran yang dapat diberikan antara lain bahwa program stimulasi hendaknya dilakukan oleh orang dewasa yang berinteraksi dengan anak dalam kegiatan sehari-hari, sehingga menjadi bagian dari keseharian anak, guna mendukung pertumbuhan dan perkembangan yang optimal. Perlu juga dilakukan sosialisasi secara intensif kepada orangtua, yang salah satunya melalui program parenting education, sehingga stimulasi dapat juga dilakukan di rumah.

\section{DAFTAR PUSTAKA}

Roeber, Barbara J, Christa L. Tober, Daniel M. Bolt, Seth D. Pollak. (2012). Developmental medicine and child neurology: gross motor development in children adopted from orphanage settings. Waisman Center and Department of Psychology, University of Wisconsin-Madison. Madison Gallahue, David L. (1989). Understanding motor development infant, children, adolescent. MacMillan Publishing Company. New York
Papalia and Feldman. (2012). Play diagnosis and assessment.Wiley. New York

Peraturan Menteri Pendidikan Nasional No. 58 Tahun 2009 tentang Standar Nasional Pendidikan

Santrock, John W. (1995). Life span development, perkembangan masa hidup. Penerbit Erlangga. Jakarta

Woolfson, Richard C. (2005). Mengapa anakku begitu? panduan praktis menuju pola asuh positif. Penerbit Erlangga. Jakarta 